\title{
Is Judicial Mediation A Successful Choice In Internal and International Business?
}

\author{
Hoda Magdy Nour \\ Hellwan University, Faculty of Law, Hellwan City, Cairo, Egypt
}

\begin{abstract}
Because mediation and conciliation as an attempt to reach an amicable settlement to the dispute arising out of, or relating to a contractual or other legal relationship, have no effect to enforce execution, we must resort to the court if the solution not adopted voluntary. The capability of alternative dispute resolution $(A D R)$ in settle the disputes if the mediation or conciliation process includes parties from different legal systems, will completed either if the solution adopted voluntary, or by resort to the competent court to issue an award, which makes such a solution as the traditional rules. The ineffectiveness of the ADR lies in their nonbinding solution, which cannot be enforced if the parties do not agree, or not enforced voluntary. Therefore, they will lose money and time. The consent and signed solution may be presented to the court for implementation, in some cases the ADR process itself can be seen as a way of obtaining a solution agreement, and return to the court to execute the compromise settlement, because the consent award lacks of approval to the agreement reached by the parties, the court approval leads to a binding compromise settlement.
\end{abstract}

Keywords: consensual nature, alternatives, enforceability, court Intervention

\section{Introduction}

The development of international trade, reconstruction and economic relations between partners need more and more an effective Peaceful settlement of disputes through ADR techniques.

The intervention of courts in mediation or conciliation process is likely to take place at any one of these three stages:

- During the actual course of mediation process, if it faces difficulties.

- If the mediation or conciliation process fails,

- Following making an agreement settling the disputes, to render an enforceable decision.

This will be effective, especially if the court is specialized in the execution process, and follow easier procedure, this will depend on the legislative entity, either by amended law or entering in a convention .

This paper would carry out the basic notions of the "execution Alternative Dispute Resolution" (ADR), it will basically focus on methods of enforcing a peaceful settlement of disputes which being an important issue that needs special consideration.

\section{A Third Person Assists the Parties}

In ADRs the parties request a third person to assist them in their attempts to reach an amicable settlement of their dispute arising out of or relating to a contractual or other legal relationship. In mediation a voluntary and self making process, settles the dispute without binding decisions, but the parties in mediation have the advantages of confidentiality, cost effectiveness, party procedural control, and nothing will happened unless the parties agree upon (1),(2).

A mediator as a third party helps the disputing parties to negotiate amicably to reach a settlement and, his mission depends principally on shuttling between the two parties trying to convince each of them separately that a certain settlement would be for his sake and benefit.

But, in the most cases the parties acceptance and the execution of the agreement solution will depend upon what they think as just and fair, the balanced one would be acceptable and binding voluntary to them, they will do as the traditional rules of behavior decided by customs and moral rules, and if the mediation or conciliation process includes parties from different legal systems the potential problems of recognition and enforcement are avoided.

\section{The Assistance of the Court}

Whether conciliation and mediation are one technique, as common law jurists consider, or conciliation as a method or technique different from mediation as some civil law countries see(3), differentiating between the procedure and the enforceability of settlement agreements in mediation and conciliation have no legal or practical importance. Both of them because of their non abidingness need the assistance of the court in the most cases, especially where the parties have all joined together in a form of agreement which makes such a solution (4).

In both, if a Settlement discussion fails to reach a settlement agreement, the parties will call to arbitration or litigation. Because, ADRs have no effect to exclude the court or arbitration jurisdiction, as the case may be, this will enable the parties to resort to the court at any time, and apply to enforce the reached settlement agreement pursuant to the general rules.

Even if there is no special mediation law in the country, the agreements arising from mediation and conciliation processes could be submitted to the court as an agreement, not mere as a fact.

\section{Volume 4 Issue 12, December 2015}




\section{The Different Assumptions}

We could talk about execution of the agreements arising from mediation and conciliation processes as ADRs from more than one aspect :

The first one, when the parties begin with mediation or conciliation.

The second, when the parties deciding in the course of judicial or arbitral proceedures to go for mediation or conciliation .

The third, if and when the parties belong to more than one country, the foreign settlement agreements may or may not be able to seek direct enforcement at the place of enforcement.

The fourth, when a judge or an arbitrator, in the course of judicial or arbitral proceedings asked for, or attempts to facilitate a settlement, and the parties agree.

The four assumptions could be discussed futher below :

\subsection{The first assumption : The parties begin with ADR process:}

The wording of the agreement to apply mediation may be agreed and signed stating that : "Any disputes arising from or related to the contract shall be settled by the parties through mediation by a third party, in case of no settlement agreement is reached in a fixed time, the dispute may be submitted by any party to litigation or arbitration as the case may be".

The Suitable solutions in the mediation process would be accepted, especially when the parties see neturality and feel trust. Otherwise, although all efforts and expenses the parties will not accepting, or enforcing the settlement (5).

The parties usually arrange a two-step dispute resolution procedure, firstly they begin with friendly discussions, and if this fails the parties seek litigation or arbitration.

If one party fails or refuses to attend or take part in all or some of the proceedures, the mediation process will fail, and declare the end of the proceedures, because the parties, unlike the case in arbitration, are permitted to withdraw from the procedures at any time.

Because the parties is the main elements in mediation process, they need to reach by themselves to an agreeable resolution, therefore the result of each party' decision depends on the other's decision, and the final outcome may be better for both parties if they co-operate.

When the disputed parties begin with a mediation or conciliation process and reach a consensual settlement agreement, and if the solution was not executed voluntary, either party will resort to the court, to execute the compromise settlement, because it has no effect to enforce execution, and the agreement was not recorded in a judicial decision or in an arbitral award, therefore the other party needs to raise the issue of enforceability of the settlement agreement.

This consensual mediation agreement which was signed by the parties themselves, or their representatives, unless enforced voluntary either party could submit an application before the judge, and enforcement will granted if the agreement is issued according to general rules of the law .

Although it is a consensual settlement agreement issued by the parties, the enforcing authority may not facilitate the enforcement proceeding than the regular execution.

This needs to present specialized courts taking into account the enforceability as an instrument different from regular one, which facilitate the execution of the compromise settlement

The application for challenge or refused its enforceability may not be admissible if the agreement signed from the parties, unless there is a fraud or if it relates to a non mediatable matter.

\subsection{Second Assumption: Parties After Submitting A Dispute To A Court Or An Arbitral Tribunal Begin The ADR Process}

When the parties in some cases, after submitting a dispute to a court, or to arbitral tribunal, and at later stage reached an agreement during the judicial or arbitral procedures to initiate a mediation or conciliation process.

In these situations where there was a mediation or conciliation process started during the judicial or arbitral proceedings, the agreement will recorded in a judicial decision or an arbitral award, therefore this will not raise the problem of enforceability of settlement agreements, because it will be enforced as a judicial decision or an arbitral award.

But even in this case still need to facilitate the procedure of enforcement of the a judicial decision or an arbitral award, because of its complexity.

\subsection{Stay the Court Proceedings}

When the mediation agreement is agreed on and signed after the disputes submitted to the court, the court has no authority to refuse the parties' request to stay the court proceedures when mediation agreement rightly concluded after occurrence of a dispute, and a lawsuit has been submitted to the court.

The courts may at its discretionary power refuse to refer the dispute to mediation, and retain jurisdiction for itself, especially if one of the parties is reluctant to refer the dispute to mediation.

The court will order to stay the court procedures, and refer the parties to mediation in a limited time to enable the parties to agree amicably. The court might refuse to stay the procedures in some cases if there were good reasons for that, as it may be if the action takes place, and their request to stay the action submitted after the end of the court proceedings.

\section{Volume 4 Issue 12, December 2015}




\section{International Journal of Science and Research (IJSR) \\ ISSN (Online): 2319-7064}

Index Copernicus Value (2013): 6.14 | Impact Factor (2014): 5.611

Also, the court will not give effect to an invalid clause, such as if the dispute involves people other than the parties of the agreement, or when it has not been freely accepted. This defective mediation agreements as inoperative, uncertain or inconsistent, can be worthless, as the court will not put it into effect.

The court will retain their jurisdiction, only stay the case for limited time, after that it will declare that the settlement succeeded, or decide the dispute on their own rules.

If the parties determine a certain time in the mediation agreement, within it they must reach a settlement, either party may return to the court if the mediator does not fulfill the mission within the time frame agreed on.

The extents of mediator authority determined in the agreement of the parties, which is the only source of his jurisdiction, no other limitation may imposed on by the court. The parties will exercise their roles under the mediator's help and support, sharing in facts and solutions otherwise delay and cost consequences.

The mediator helps in evaluating the validity of each party's position, this will change the perceived strength of the party's rights, both legal and contractual, to find a settlement, this will facilitate to reach a compromise, taking into account that the solution resulted from the mediation process it may be typically to the disputes which submitted to the court, or may be the process continue to reach a partial solution, or even the parties agree on the legal bases for the settlement, they may raise some question as to how perform the mutual obligations ,or who is responsible to the compensation, and leaving the determination to the claims to the court decision, otherwise, return to the court to judge the dispute (4).

If the mediator exceeds the limits of the mediation period, either party- notifying the other - may ask the mediator or the court, as the case may be, to declare that the mediation has failed and terminate the mediation proceedings, either party may return to the court to continue.

The court will terminate the mission of the mediator, and continue in rendering award, it may upon the request of the parties continue as a mediator on the same basis agreed if the rules conferred the judge this authority.

In Egypt mediation mechanism to settle civil and commercial disputes, "Solh" is a technique leading the parties to settle their disputes, in art.25 in procedure Civil law no. 13 /1968 permits the parties to agree, during the juducial proceeding, on settlements ending the dispute, before the judge, such decision should have the force of the judicial award. This art gives this facilities, even it needs to amended by give this mission to a special judge.

Pursuant to Egyptian Arbitration law No.27/1994, the parties may agree during the arbitral proceeding on settlements ending the dispute, such decision should have the force of an arbitral award as far as execution is concerned. As Art 41 states that "If the parties agree, during the arbitral proceeding, on a settlements ending the dispute, they may request that conditions of the settlement be evidenced before the arbitral panel, which must in such case issue a decision containing the conditions of the settlement and terminating proceedings. Such decision shall have the force of an arbitral award as far as execution is concerned.

Besides, the law no.9/1997 permits administrative bodies to go to arbitration, as the law authorizes the parties to empower the arbitrator to settle the dispute amicably by a binding decision, without restriction by law and without reasoning .

\subsection{Third Assumption: The disputes mediated by the judge in judicial mediation}

The Judicial mediation is a situations where a judge or an arbitrator, in the course of judicial or arbitral proceedings, attempted to facilitate a settlement.

According to Sharia, the duty of the judge is to encourage the parties to settle their dispute amicably, but in civil law the judge may not at his own initiative encourage the parties to settle their dispute amicably or suggest solutions, instead this would be considered unethical.

If the parties agree to settle the dispute amicably, this will give the parties whatever their capacity the right to agree on mediation.

As regards settlement agreements involving foreign entities, could be addressed under the article V(1)(a) of the New York Convention, should be excluding settlement agreements involving government entities entirely excluded in some jurisdictions where, government entities were not authorized to conclude them. the United Nations Convention on Jurisdictional Immunities of States and Their Property (2004), yet to enter into force (5)

The Egyptian prime minister established a ministerial committee presided by the minister of justice to settle investment disputes, its recommendation would be obligatory for the state and would be enforced if the other party accepted, this is a case of amicably special mission leading to a kind of judicial decision, decided to encourage investment in Egypt (9).

Also, in Egypt is a new trend the ministry of justice in Egypt drafted a new legislation of judicial mediation, still rendered yet, it is expected to make a tribunals consists of judge and two merchant members, or members of other specializations, to settle the disputes submitted to them by the parties who agree in writing on this by their free will, this law draft states a kind of combined justice, there is some suggestions to refer it to mediator and then return to judge .

Most new arbitrations law in Arab country which influenced to great extent by the model law permit the arbitrators to settle the dispute as amicable compositors. The expensive arbitration fees will be a difficult one, so the arbitral institution should states that will eliminate the fees if the parties reached a settlement.

\section{Volume 4 Issue 12, December 2015}




\section{International Journal of Science and Research (IJSR)}

ISSN (Online): 2319-7064

Index Copernicus Value (2013): 6.14 | Impact Factor (2014): 5.611

\section{Feature of Judicial Mediation:}

In judicial mediation, the parties agreement specify the power conferred upon mediator.

Each shared by a judge and two merchant members, or members of other specializations to settle the disputes submitted to them by the parties who agree in writing on this by their free will.

The state court has advantages over mediator because it receives its authority from law, and has coercive powers that ensure obedience to its decisions, the mediator does not have these powers, and the parties cannot confer upon him these powers over property and persons

A court might review some of the defences for procedural efficiency; in foreign settlement agreement the law applicable with respect to defences in the enforcement procedure should be applicable depending on the defences.

For example, the court might need to consider the law applicable to the parties in relation to capacity, to the enforcement procedure, to the settlement agreement and to the mediation or conciliation process (10).

If the parties does not compel with agreed resolution and not executed voluntary, these agreements reached in the course of judicial proceedings should be considered as judicial or award, it will not raises the enforceability of settlement agreements because it will rendered in a judicial award

The judicial process will not almost consensual, the agreements reached following such a procedure would not have the same nature as agreements reached as a result of a judicial process, therefore it will submit to execution in a special procedure not as this applied on judgment award, this will suggest to a special court and easier procedure.

Whereas the mediator may or may not involved in the drafting or preparation of settlement agreements, the judge will drafting and rendering it. Whereas the mediator completes his mission when the parties reach a final settlement to their dispute, or fail to agree, the judge will continue and rendering the award

The role of the judge as a mediator is different, he should fell and let the parties see that he guides the parties to a mutually beneficial resolution of their dispute, helps the parties to decide for themselves.

The role of judge as a mediator is to act as amiable compositor which has the power to decide the case according to standard of equity or ex aequo et bono. The mediator, works in an unbiased manner, taking a balance role towards both of them, not influenced by nationalities or position of the parties, or financial and political matters in the disputes.

Mediation process is differ from judicial one, both could not be equated in proceedings, the mediator is not bound by the provisions of law, and the importance difference is that the mediator does not adjudicate the merits of the dispute nor according to the law or to the justice and equity, he is not decide or rendered an award, the parties are who decide and signed, but the judge when he act as a mediator, he will rendered the award .

The other difference is that, whereas the parties have the liberty to choose the mediator or the way in which they are chosen, the court will impose judges appointed as a mediator, regardless the consent of the disputed parties

May the rules give the chance to arrange at the request of the parties a preliminary meeting with the proposed one to persuade them, the judge as a mediator have to arrange for meetings to hear the parties very carefully, and for deliberation with them, such meetings may be held unilateral firstly, then hold a meetings with both of them to enable each party to explain and express his points of view and arguments.

The parties notified of the scheduled dates sufficiently in advance, summary minutes of each meeting shall be recorded and a copy thereof shall be delivered to each of the parties unless they both otherwise agree.

Usually, the cost of initiating the mediation procedures under auspices court is considerably lower than bringing the same dispute before an institution, if the mediation is under auspices of the court under the judicial mediation the court will be the place, and will use the court facilities.

\section{Fourth Assumption: different countries \&procedures}

If the mediation or conciliation proceedings were taking place in the same country they dealt with issues as the judicial or arbitral proceedings and the enforcement procedure as in the same nature, the matter will not issue the problem of foreign law.

Whereas, The party in the foreign settlement agreements, would be able to seek direct enforcement at the place of enforcement, either as to articles of the New York Convention, or pursuant to the rules of enforcement law, which will apply even where Whereas mediation is fully consensual, and the parties consented to it, the court enforcing authority will applying the applicable law.

The validity of the process constitute a ground for accepting enforcement when the mandatory procedures and the other requirements were complied with under the New York Convention, if there is no domestic law in mediation, the parties in international cases belong to different cultures, they don't have common forms or common understanding, rather they have different ADR techniques and processes.

Therefore it will depend on the agreement of the parties and the requirements of the agreement to Mediation .

This means that the court will give the order of execution after ascertain the requirements and the validity to give the settlement agreement the effect, the court will refuse 


\section{International Journal of Science and Research (IJSR) \\ ISSN (Online): 2319-7064}

Index Copernicus Value (2013): 6.14 | Impact Factor (2014): 5.611

enforcement if that settlement agreement had been found to be null and void.

Although the parties consent, the settlement agreement will not enforced if it being invalid, where the subject matter of the settlement agreement was not capable of being settled through a mediation or conciliation process, or the obligations contained in the settlement agreement were not capable of being enforced.

Due process in mediation is differ from conciliation, and both could not be equated to that in arbitral proceedings, although all they permitted to depart from the strict application of law, the mediator is not bound by the provisions of law, a public policy apply to an arbitrator - even when he act as amiable compositor - and mediator as well. but the importance between them is the mediator unlike arbitrator even when he acts as amicable compositor he does not adjudicate the merits of the dispute nor according to the law or to the justice and equity, he is not decide or rendered an award ,the parties are who decide and signed but the judge when he act as a mediator, he will rendered the award .It is not true, or it is not always true to says that: "Every court case, by its mere existence, is a scandal troubling the natural order", or also to says that : it is in the common interest of the community to prevent matters reach this last stage $\left({ }^{6}\right)$.

\section{Is the Mediator's Role to ensure the enforceability:}

Because mediation mainly depend on the agreement of the parties which defines the type of authorization and the mechanism(7), the mediator has no jurisdiction to issue a binding decisions or decide an order, if they fail to agree on and sign $\mathrm{it}^{(8)}$.

A mediator will discuss the matters without limits, and may deals with matters not falling within the agreement, simply because he is not only does not issuing an award, rather the parties will do and signing it to make it enforceable voluntary, or the court rendered an award .

And because both the domestic and international differences and disputes may be settled by resorting the parties to litigation or other way as ADR, the parties expectations that the mediator will helping them in rendering the agreement in acceptable form to execute ,by advising and convincing the parties to do so ,unless they agree to enforced voluntary.

The mediator will be guided by principal of law helping the parties' case, to reach a settlement in acceptable form to execute without rigid formality, giving consideration to the rights and obligations of the parties, and the circumstances surrounding the dispute, including any preconditions in the law.

Because a mediator by having an active and greater persuading role, putting the disputed parties to negotiate amicably to reach a settlement, helping them to submitted a better case and acceptable solution, and his mission depends principally on trying to convince each of them that a certain settlement would be for his sake and benefit, and it is enforceable.

\section{The limits of court's authority upon the suggested} solution:

According to the mediation mechanism in most cases settlement reached agreement will applied voluntary, and rarely occurs the need to relay on the cooperation of state courts.

The mediation proceedings if succeeded, will end with an award, which will be final and binding upon the parties signing, the parties undertake to carry out the award without delay.

In mediation mechanism the parties co-operation produces voluntary enforcing, but when the parties reject to execute the decisions made by the parties, they might let either party to resort to the court, this will destroy the mediation mechanism as a voluntary method.

The court in ordering to execution ,should not agree on the solution to order the enforcement, or control on mediation stages or procedures, but will correct errors either in computation, clerical or typographical, or any errors of similar nature, either on its own imitative, or upon the request of either party.

Mediation agreement may be exchanged by acceptance between them orally even if suggested by one party, and not denied by other, this unwritten mediation agreement would be considered as a right agreement of mediation, unless either party alleged lacks of acceptance of both parties.

The settlement agreements should include various information on the dispute, and that the dispute was settled in part if the parties give him partial limitation concerned with some disputes or claims not in a whole.

According the provision of the law, the form of the drafted award should not be in the formal shape, but it must be signed by the parties and the date and the place where it was rendered, even if there is no signature by the mediator or his name.

Any decision, settlement or reached agreement unless applied voluntary, is subject ultimately to the court control as to order public and general condition, and the validity requirements of the mediation agreement should be concluded by a free and valid will of the parties, each party to a mediation agreement must have legal capacity to enter into that agreement, otherwise, it is invalid, either the natural or moral parties were under some incapacity the settlement may be refused and the agreement may be set aside.

\section{A need for a specialized court for mediation and conciliation agreement execution:}

The parties might reached an agreement that would resolve their dispute initiatively from the beginning, or

In the course of a judicial or an arbitral proceeding, as a result that agreement might be recorded in the form of a judicial decision or an arbitral award on agreed terms, this 


\section{International Journal of Science and Research (IJSR) \\ ISSN (Online): 2319-7064 \\ Index Copernicus Value (2013): 6.14 | Impact Factor (2014): 5.611}

will had the same effect as a court judgments and were enforceable as such.

But the procedures of judicial and arbitral execution are suffering from delays and obstacles in implementation and execution of judicial and arbitration awards ,and of Slow rulings in action order of execute the judicial and arbitration awards and the challenge mechanism provisions, which this consensual settlement agreement not only did not need, but also suffering from.

The fact that actually needs legislative amendment of executive judicial and arbitration national provisions, which concerned to introduce a specialized court for mediation and conciliation agreement execution with a simplified procedures disciplined review and identify ways to appeal and review.

The court will be specialist in mediation and conciliation agreement execution, and when the mediation process include parties from different legal systems procedural patterns, the procedure should reflect the harmonization of legal cultures depending on party autonomy which permitted the parties and the mediator to benefit from mediation and conciliation proceedings, which must reflect a procedural flexibility in dealing with the execution procedure by The means of implementation that provide an easy and affordable one, while retaining the basic guarantees and identify ways the grievance and appeal procedures for implementation, with diligence and ensure the achievement of and having full opportunity to the either party in presenting his case, and be treated on equal bases with other party.

The court in rendering an execution order to the mediation agreement or mediation agreement rendered in an judicial or arbitration award, shall be enforced in conformity with this law, and in accordance with the provisions of the New York convention.

It is important to convince that there is a need to special court and procedure for mediation and conciliation agreement and execution.

In relation to the notion of mediation or conciliation, and in regard with the consensual nature the judicial or arbitral settlement award, it would should be final, and excluded from the scope of appeal, and the court decisions that considered the validity of the settlement agreement as a precondition for the execution, will declare with reasoning, the validity or nullifying the settlement agreement, and no appeal will be permitted, providing for a simple review mechanism could facilitate the enforcement procedure, the court exequatur should provide an efficient and simplified enforcement mechanism.

May be is the United nation as the modern Trent, putting a legislative framework, model provisions or guidance in relation to enforcement of settlement agreements, but even this happened still we need a legal instrument and specialized court.
Any objections or defences to enforcement could be raised to the court, the court review will insure the validity and the signature of the settlement agreement.

\section{Execute national and foreign settlement agreements:}

The courts are authorized to determine prima facie certain questions, such as the validity of the settlement agreement and fulfillment of procedural requirements, In foreign settlement agreements such review would be the same when a party to a foreign settlement agreement would be able to seek direct enforcement at the place of enforcement without imposing a higher requirement for a review of the settlement agreement more than at the originating state.

Pursuant to article V(1)(e) of the New York Convention importing specific requirements on international enforcement process, lack of due process in mediation taking into account the various techniques of conciliation, should be considered as a specific defence and that any settlement agreement that disregarded due process should not be enforced.

The elements of due process in mediation would be considered in the broader context of procedural public policy.

There is no cause neither for impartiality and neutrality of the mediator, nor exceed the authority because there is no mandate in deciding issues, or breach the confidentiality of the proceedings and, or even non equal treatment of the parties because ,unlike in the arbitration are, the solution or the settlement agreement issued and suggested from the parties themselves, and signed consensual, does not imposed from outside.

Moreover, the parties could fall back or withdraw and leave the process if they or, any of them feel partiality or even undue pressure from the mediator or conciliator, and the more important difference is the execution of it is that there is no cause to annulment except the validity or the signature of the settlement agreement, and the consideration of public policy, the valid agreement and right consensual signature is vital in accepting execution.

This will facilitate the expedited enforcement, the court will preserve the flexible nature of the mediation process, because the outcome of mediation is an agreement and not a binding decision imposed by a third party,

This is in conformity with even sharia, and present law. Even the breach of confidentiality will not affect the validity of the agreement, rather it will cause-if proved-the responsibility of the mediator. As the Model Law addressed in art "8" which states: when the conciliator receives information concerning the dispute from a party, the conciliator may disclose the substance of that information to any other party to the conciliation.

However, when a party gives any information to the conciliator, subject to a specific condition that it be kept confidential, that information shall not be disclosed to any other party to the conciliation.

\section{Volume 4 Issue 12, December 2015}




\section{International Journal of Science and Research (IJSR) \\ ISSN (Online): 2319-7064}

Index Copernicus Value (2013): 6.14 | Impact Factor (2014): 5.611

It is obviously that settlement agreements should include enforceable obligations, which to be enforceable it will be in writing and indicate the agreement of the parties to be bound by the terms of the settlement.

Also to facilitate the expedited enforcement, and the acceleration, the request for enforcing should indicate the requirements, and it is the party against whom the settlement agreement was being invoked could object to the enforcement by furnishing proof to support its defence of the invalid agreement or lack of right consensual signature objecting the execution,

\section{Recognition of a foreign settlement agreements:}

A distinction should be made between recognition and enforcement of settlement agreements, Term "recognition" is referred to the process of considering the award as binding but not necessarily enforceable, while "enforcement" referred to the process of giving effect to the award.

The New York Convention provided for the recognition of arbitration agreements as well as arbitral awards.

Recognition is a procedure usually applied to give legal effect to a court decisions, which rendered in another State, the enforcement of the foreign settlement agreements is to execute the awards which made in the territory of a state other than the which where the enforcement of such settlement agreement was sought.

At the recognition stage, the validity of the mediation procedure and its outcome, it might be examined, and declare the recognition of the agreement by a court, with consideration that in mediation unlike, arbitral awards, it could be difficult to determine the origin state of settlement agreements because of not only the very parties freedom to choose the place of mediation, but also that there is no significant distinction between national and international settlement agreements, or distinction between national and international mediation process, except it will be executed by issuing a decision court, and executed them as a judge award unless enforced voluntary as expected.

The decision court will executed as a judge award may be take place in any country, the enforcement of the foreign settlement agreements under the New York Convention, would also apply to settlement agreements not considered as domestic settlement agreements.

UNCITRAL has issued model law on conciliation adopted by the General Assembly of the United Nations on September 2002 ,countries may be adopted as it is or varied.

In the countries which applying Model Law on Conciliation, pursuant to article 1(4)(a) of this Model Law on Conciliation, a settlement agreement would be considered international where at least two parties to the settlement agreement had their places of business in different States at the time of the conclusion of the settlement agreement.
Also article 1(4)(b) of it states that the enforcement of a settlement agreement between parties having their places of business in the same State might also have an international element, as if one of the parties had to enforce that agreement in another State where assets were located.

\section{Declaring the nullity of mediation clause will frustrate the settlement agreement:}

Unlike arbitration, mediation clause do not usually form part of a contract between the parties. When a mediation clause included in a contract, the clause refers to future disputes, such agreement would have effect when the dispute has risen, the mediator may succeeds in persuading the parties to enter into a mediation, but neither the mediator or the court will impose on them, when one party refuses to honor the clause of mediation.

The full and valid consent of the parties, especially when the defendant agrees before the court to go to mediation in this case no need to be in accordance with the agreement as it in arbitration.

If the mediation is in matters which are not permitted to compromise, like personal status as capacity of persons and validity of marriage, or related to the determination of the criminal responsibility, except the compensation resulted from any illegal act, it may be ,or even highly advisable, subject to mediation.

In addition to the mediation organizations and institution keen on coordinate in relation to a preferred approach, and considered how the term mediation and conciliation should be understood, the different institution can provide the place and the facilities.

Furthermore, as to the amount of their fees it may reduce in regard with mediation unlike arbitration, rather includes easier techniques of conflict resolutions, and because of the settlement agreement might not be the final resolution of the dispute, and the obligations therein were partially or fully performed by the parties or not.

In international investment the transaction involves more foreign parties, these parties is likely to have contradicts in interests like the seller, buyer, broker, transporter, insurer, forwarding agency, Bankers or, financial institutions, or as joint venture construction contract or civil engineering or erection of plant may well involve the employer, Consulting, subcontractors, each party will not accept to defend himself or even cast the blame on, and will refuse to obtain a financial indemnity from a third party, so and when a party gives any information to the mediator, subject to a specific condition that is to be kept confidential, that information shall not be disclosed to the other party, and all transcripts and records cannot be presented to court as an evidence, unless the parties agree on that in any time (10).

\section{We conclude that:}

Mediation techniques provide certain advantages, to promote mediation as an effective means of solving disputes, need an

\section{Volume 4 Issue 12, December 2015}




\section{International Journal of Science and Research (IJSR) \\ ISSN (Online): 2319-7064}

Index Copernicus Value (2013): 6.14 | Impact Factor (2014): 5.611

specialized court applying accelerated and uncomplicated enforcement procedure which would favor settlement agreements, the current sequences and method of current procedures and requirement could harm the informal nature and amicable atmosphere of the mediation process .

The mediator, who does not impose neither his decision, nor his opinion, excreted un agreement not imposed on them from the outside, therefore the settlements be brought forth from within the parties themselves, on the basis of their interests, the mediator is not a judge or an arbitrator, he just assists the parties to overcome their continence and find a solution based on legal and objective $\backslash$ justifications or, rather on factual and acceptable bases.

A mediator is authorized not to settle differences between different people by suggesting settlement, but he is under a duty to act impartially helping the parties to reach their own determination of the matters in a fair and unbiased manner, and accepting voluntary.

Although the settlement agreement may be surprisingly finally emerges different from any initial proposals or applications, as a result of the parties co-operation in presenting the mediator with information in connection with the dispute, then the mediator may be able to conclude his mission.

In default of the parties agreement on a mediator ,or if they failed to reach a solution, or refused in both, or one of them the mediator's suggestions, the court is authorized upon the parties, not under the obligation to decide over the dispute.

Due to the current factual and legal obstacles posed a number of challenges, which needs solutions to address enforcement of settlement agreements, legislation determined specified court and procedure trusted the enforcement of settlement agreements.

Even if there is further cooperation should be done and coordination in between governments in relation to formulate a feasible and possible form, and although the international bodies focus and efforts to identify relevant issues and develop possible solutions to facilitate enforcement of settlement agreements (10).

The grounds for refusing enforcement will be handled in a flexible manner, it will be denied if a party to mediation did not sign or consent to the agreement, or the settlement agreement was obtained by fraud or did not reflect the terms agreed to by the parties. the concept of mediability relates of public policy limitations.

A need for a special court for mediation and conciliation agreement execution is a very critical legal issue.

\section{References}

[1] E. Mark Appel, "Partnering New Dimensions in dispute prevention and resolution", Journal of International Arbitration, 1993 .
[2] Crossing the Line: Dispute Management and Dispute Avoidance through Partnering, In Proceedings of the International Chamber of Commerce conference, International Commercial Disputes: New Solutions? Bruxelles, 24, Oct, 1995.

[3] M. Aboul-Enein, Peaceful Settlement of commercial Disputes, 2005.

[4] Richard Hill, The Theoretical Basis of Mediation and Other Forms of ADR: Why They Work, Journal of International Arbitration,Vol.14, No.2, 1990.

[5] Users of Mediation, International Mediation Institution, The 6th Annual Conference report, on November 10, 2015.

[6] JOHANNES TRAPPE, Conciliation in the Far East, Journal of International Arbitration, 1989.

[7] Richard Hill, Non Adversarial Mediation, journal of international Arbitration,Vol.12,No.4,1995.

[8] Alan Redfen-Martin Hunter. Law and Practice of International Commercial Arbitration, Sweet\& Maxwell, 2003.

[9] N. Hoda, Mediation Choice, the new Arab's trend to protect internal and International investments, . [Online] Available: J Am Sci2015;11(X):X-X]. (ISSN: 15451003).http://www.jofamericanscience.org.

[10] United Nations Commission on International Trade Law, Forty-ninth session New York, 27 June -15 July 2016, Report of Working Group II (Arbitration and Conciliation), sixty-third session (Vienna, 7-11 September 2015).

\section{Author Profile}

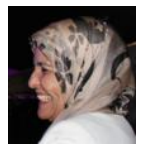

Hoda Nour received the B.S. and M.S. degrees in Law from Faculty of Law, Cairo University in 1985 and 1987, PHD in Arbitration, "The role of arbitrator and limits of his authority", Cairo University in 1997. She is now Member in Helwan university "School in Commercial and civil procedures Department, Faculty of Law, Helwan University, Cairo, Egypt. 